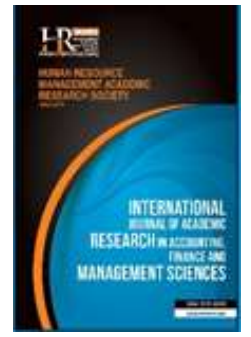

International Journal of Academic Research in Accounting, Finance and Management Sciences

Vol. 10, No.2, April 2020, pp. 31-34

E-ISSN: 2225-8329, P-ISSN: 2308-0337

(c) 2020 HRMARS

www.hrmars.com

To cite this article: Sormin, F. (2020). The Influence of Size, Leverage and Corporate Social Responsibility on Tax Avoidance, International Journal of Academic Research in Accounting, Finance and Management Sciences 10 (2): 31-35.

\title{
The Influence of Size, Leverage and Corporate Social Responsibility on
} Tax Avoidance

\section{Feber Sormin}

\author{
Universitas Mercu Buana, Jakarta, Indonesia \\ E-mail: feber.sormin@mercubuana.ac.id (Corresponding author)
}

\begin{abstract}
The research aims to examine the effect of company size, leverage and corporate social responsibility on tax avoidance. Using sample selection of purposive sampling in the population of manufacturing companies in the Paper and Advertising Industry, Printing and Recording Media sub-sectors because the condition of the company remained stable despite the economic crisis. Data processing multiple linear regression analysis with SPSS statistics found that partial leverage has a significant effect on tax avoidance while company size and Corporate Social Responsibility do not have a significant effect on tax avoidance.

Key words

Tax Avoidance, Size, Leverage, Corporate Social Responsibility

Received: 13 April 2020 (c) The Authors 2020

Revised: 11 May 2020 Published by Human Resource Management Academic Research Society (www.hrmars.com)

Accepted: 19 May 2020 This article is published under the Creative Commons Attribution (CC BY 4.0) license. Anyone may Published Online: 09 Jun $2020 \quad$ reproduce, distribute, translate and create derivative works of this article (for both commercial and terms of this license may be seen at: http://creativecommons.org/licences/by/4.0/legalcode
\end{abstract}

\section{Introduction}

As we know, that Tax has a very important role for a country in financing government activities as well as the role of the tax function that can be as a Budgeter, Regulation, Distribution and stability function. Tax revenue is used in financing set in the State Budget (APBN). However, taxpayers will always try to minimize the tax burden that will be paid to the state. To minimize the tax burden, taxpayers can do a variety of ways both legally and illegally. Some taxation cases that occur, it is suspected that there are still many companies that do tax avoidance. Various attempts were made by company management to avoid tax to be suspected one of the causes. In fact, tax avoidance or tax non-compliance can also get a reaction from investors (Tarmidi, 2019). Several factors were found to influence taxpayers in conducting Tax Avoidance, such as Corporate Size, Leverage, and Corporate Social Responsibility.

One of the factors that influence tax avoidance is company size. The greater the size of the company, the transactions will be more complex, so that there is a large enough gap for management to avoid tax. Dewinta \& Setiawan (2016), Kurniasih \& Sari (2013), Puspita \& Febrianti (2017) in their research found a significant effect of company size on tax avoidance, although the opposite results were found Cahyono et al. (2016).

Another factor that influences tax avoidance is leverage, which is the ratio used to measure the extent to which a company's assets are financed by debt. In other words, solvency ratios or leverage ratios are used to measure a company's ability to meet all its obligations, both short-term liabilities and long-term liabilities. This means that if the higher the debt to a company, the interest expense incurred will also be higher. If the interest expense is high, it will reduce the company's profit. With reduced profits at the 
company, it will directly reduce the tax debt that will be paid to the state. Putri et al. (2016); Sormin (2019) in their research found the effect of leverage on tax avoidance, although the opposite results were found Cahyono et al. (2016); Hidayat (2018) and Kurniasih \& Sari (2013).

Corporate Social Responsibility (CSR) is a private or corporate social obligation to the community and the government as a result of the expansion of its business which may have disrupted the environmental and social balance in which they carry out their activities. By implementing Corporate Social Responsibility (CSR), the company incurred costs in implementing it, so it can be interpreted that the more companies do the practice of Corporate Social Responsibility (CSR), it will add to the burden of the company which consequently can reduce company profits in a period, so the impact has an impact on the magnitude the amount of tax to be paid to the state. Lanis \& Richardson (2013) in his research found a significant relationship between Corporate Social Responsibility and tax avoidance.

This study uses data from manufacturing companies in the Paper and Maritime Industry sub-sector, printing and recording media listed on the Indonesia Stock Exchange (BEI) in 2015-2017 because this company is a company producing goods and primary needs of individuals, so that they can survive even in economic conditions who are not friendly. However, based on data from the Directorate General of Taxes Receipt that the tax revenue for the Paper and Goods Industry sub-sector as well as the Advertising, Mapping and Recording Media industries from 2012 to 2016, there are tax revenues that go up and down every year.

\section{Literature review}

\subsection{Conceptual Framework and Hypothesis Development}

The size of the company is a comparison of the size and size of an object. If the linking is related to a company or organization, then the size of the company can be interpreted as a comparison of the size of the business of a company or organization. Company size is a scale in which the size of the company can be classified according to various ways, including the total assets, market value of shares, and others. The size of the company is divided into 3 categories, namely large firm, medium firm, and small firm. The larger the size of the company, the transactions will be more complex. So it allows companies to take advantage of existing loopholes to carry out tax avoidance actions from each transaction. Dewinta \& Setiawan (2016); Swigly \& Sukartha (2015); Waluyo (2017) in their research found a significant effect of company size on tax avoidance.

\section{H1. Corporate Size has an influence on tax avoidance}

Leverage is a ratio used to measure the extent to which a company's assets are financed by debt, one of which is measured by DAR (Debt to Asset Ratio). It is also a debt ratio that is used to measure the ratio between total debt to total assets, meaning how much the company's assets are financed by company debt. If the higher the debt to a company, the interest expense incurred will also be higher and will reduce the company's profits until the tax costs are also low. Putri et al. (2016); Swigly \& Sukartha (2015); Sormin (2019) found the effect of leverage on tax avoidance. So, the lower the debt used in financing company assets, the company tends not to try to avoid tax.

\section{H2. Leverage has an influence on tax avoidance.}

By implementing Corporate Social Responsibility (CSR), the company incurred costs in implementing it, so it can be interpreted that the more companies do the practice of Corporate Social Responsibility (CSR), it will add to the burden of the company which consequently can reduce company profits in a period, so the impact has an impact on the magnitude the amount of tax to be paid to the state. Lanis \& Richardson (2013) in his research found a significant relationship between Corporate Social Responsibility and tax avoidance.

\section{H3. Corporate Social Responsibility has an influence on tax avoidance}




\section{Methodology of research}

\subsection{Population and Sample}

The population in this study was carried out in manufacturing companies in the Paper and Advertising, Printing and Recording Media sub-sectors listed on the Indonesia Stock Exchange from 2015 to 2017. In this study the researchers used Purpusove sampling, which is sampling based on research needs, meaning each unit/individuals drawn from the population are deliberately chosen based on certain considerations. There are 10 sample companies that meet the criteria, with observations of 3 years, the data analyzed are 30 data.

\subsection{Operational Variable}

In this study, Tax Avoidance as an independent variable is measured using the Effective Tax Rate (ETR) indicator, which can reflect a fixed difference between book calculations and fiscal profit through calculations based on company financial statements. Company size is a scale or value in which companies can be classified on the basis of total assets. Kasmir (2015) states that leverage is a ratio that measures the amount of debt that a company uses to finance its business activities when compared to using its own capital. In this study, leverage is measured using DAR.

The Corporate Social Responsibility (CSR) assessment uses the GRI (Global Reporting Initiative) index guidelines that apply internationally and has been widely used in many countries, one of which is in Indonesia. The number of CSR is 91 items which are grouped respectively in indicators, 9 Economic Performance Items, 34 Environmental Items, Labor Practices and Actuality of Work 16 Items, Human Rights Rights 12 Items, Community 11 Items, and Product Responsibility 9 the item. Scale of measurement of corporate social responsibility (CSR) Referring to the Global Reporting Initiative (GRI) G4 with a nominal scale (dummy), ie each item in each category of disclosure is given a score of 1 so that, if the company discloses only 1 item will be given a score of 1 and a score of 0 if the company does not disclose. Then, the score of each item is summed to get the overall score in each company.

\subsection{Hypothesis Testing Method}

Data analysis was performed using SPSS software with several stages from classical assumptions such normality, multikolinierity and heteroskedasticity to then be analyzed the results of the overall regression (Ghozali, 2013).

\section{Results}

\subsection{Descriptive Analysis}

Table 1. Descriptive Analysis

\begin{tabular}{lcccc}
\hline Variabel & Min & Max & Mean & Std. Dev. \\
\hline Y. Tax Avoidance & -0.394 & 0.938 & 0.180 & 0.262 \\
X1. Size & 25.775 & 30.732 & 28.829 & 1.330 \\
X2. Leverage & 0.121 & 0.750 & 0.440 & 0.187 \\
X3. CSR & 0.044 & 0.110 & 0.071 & 0.023 \\
\hline
\end{tabular}

\subsection{Hypothesis Test}

Before testing the hypothesis, a classic assumption test is done in the form of normality, multicollinearity, heteroscedasticity tests. With a sign value is 0,193 and above the significance value of 0.05 so data is normal. In the multicollinearity test, all vif values below 10 , in the heteroscedasticity test with scatter plot that all data is spread so that the research data was free from the assumptions of multicollinearity, heteroscedasticity. 
Table 2. Hypothesis test

\begin{tabular}{|l|l|ll|}
\hline \multicolumn{1}{|c|}{ Variable } & Coef. & \multicolumn{1}{c|}{$\mathbf{P}>(\mathbf{t})$} \\
\hline Size (X1) & 0.139 & 0.381 & $* * *$ \\
\hline Leverage (X2) & -0.629 & 0.000 & 0.667 \\
\hline CSR (X3) & -0.067 & & \\
\hline $\mathrm{N}$ & & & \\
\hline Adj. R-Square & 30 & & \\
\hline Prob F & 0.404 & & \\
\end{tabular}

Note : $*$ Significant $10 \%, * *$ Significant $5 \%, * * *$ Significant $1 \%$

From table 2 it is known that Hypothesis 2 is accepted while Hypothesis 1 and 3 are rejected. With a positive and non-significant coefficient value above 0.05 , it can be explained that size don't have influence on Tax Avoidance. That is because basically large or small companies will certainly be in the public spotlight related to profits earned by companies, so companies often attract the attention of tax authorities to be taxed in accordance with applicable tax provisions..

With a negative and significant coefficient value below 0.01 it can be explained that the leverage has a negative effect on tax avoidance. A company is said to be solvable if the company has sufficient assets and assets to pay off its debts. So, the lower the debt used in financing company assets, the company tends not to try to avoid tax avoidance, and vice versa if the higher the debt used in financing company assets, the company can avoid tax through debt repayment.

CSR has a negative and non-significant coefficient above 0.05 , it can be explained that CSR is don't have influence on tax avoidance. This CSR is done because the company is aware that it has a social responsibility not with the aim of tax avoidance, even though by carrying out CSR activities the company incurs a substantial cost.

Although only 1 research variable has a significant influence, the adjusted $r$-square value and the good $\mathrm{F}$ value indicate that the research model is quite good.

\section{Conclusions}

This study found the following results:

a. Size has no significant effect on tax avoidance

b. Leverage has a negative effect on tax avoidance

c. CSR has no significant effect on tax avoidance

\section{Implications and limitations}

The results of this study find the effect of Leverage on Tax Avoidance, then investors can use these indicators in assessing the level of tax avoidance of entities. With no effect of size and CSR found in this study, then further research is better to use other variables in analyzing tax avoidance.

This study only uses 30 data from 10 company samples, so the results of this study may not be strong enough so that in future studies it is better to add research data so that the results are stronger.

\section{Acknowledgment}

This study supported by the Faculty of Economic and Business and Research Center of Universitas Mercu Buana, I am grateful for the supported from Dean, Rector, Research Center team.

\section{References}

1. Cahyono, D. D., Andini, R., \& Raharjo, K. (2016). Pengaruh Komite Audit, Kepemilikan Institusional, Dewan Komisaris, Ukuran perusahaan (Size), Leverage (DER) dan Profitabilitas (ROA) terhadap Tindakan Penghindaran Pajak (Tax Avoidance) pada Perusahaan Perbankan yang listiing BEI Periode tahun 2011-2013. Journal of Accounting, 2(2), 1-10. 
2. Dewinta, I. A. R., \& Setiawan, P. E. (2016). Pengaruh Ukuran Perusahaan, Umur Perusahaan, Profitabilitas, Leverage, dan Pertumbuhan Penjualan terhadap Tax Avoidance. E-Jurnal Akuntansi Universitas Udayana, 14(3), 1587.

3. Ghozali, I. (2013). Aplikasi Analisis Multivariet Dengan Program IBM SPSS 21 Update PLS Regresi. Semarang: Badan Penerbit Universitas Diponegoro

4. Hidayat, W. W. (2018). Pengaruh Profitabilitas, Leverage, dan Pertumbuhan Penjualan Terhadap Penghindaran Pajak Studi Kasus Perusahaan Manufaktur di Indonesia. Jurnal Riset Manajemen dan Bisnis Fakultas Ekonomi UNIAT, 3(1), 19-26.

5. Kasmir. (2015). Analisis Laporan Keuangan. Jakarta : PT Raja Grafindo Persada.

6. Kurniasih, T., \& Sari, M. M. R. (2013). Pengaruh Return On Asset, Leverage, Corporate Governance, Ukuran Perusahaan, dan Kompensasi Rugi Fiskal pada Tax Avoidance. Buletin Studi Ekonomi, 18(1), 58-65.

7. Lanis, R., \& Richardson, G. (2013). Corporate Social Responsibility and Tax Aggressiveness: A Test of Legitimacy Theory. Accounting, Auditing and Accountability Journal, 26(1), 75-100. https://doi.org/10.1108/09513571311285621

8. Puspita, D., \& Febrianti, M. (2017). Faktor-Faktor Yang Mempengaruhi Penghindaran Pajak Pada Perusahaan Manufaktur Di Bursa Efek Indonesia. Jurnal Bisnis dan Akuntansi, 19(1), 38-46.

9. Putri, S. E., Agusti, R., \& Silfi, A. (2016). Pengaruh Ukuran Perusahaan, Return On asset ( ROA), Leverage, dan Intensitas Modal Terhadap Tarif Pajak Efektif. JOM Fakultas Ekonomi Universitas Riau, 3(1), 1506-1519.

10. Sormin, F. (2019). Analysis of the Effect of Operational Profitability and Debt to Asset Ratio (DAR), Debt to Equity (DER) on Tax Avoidance. Empirical studies on Food and Beverage Sub-sector Manufacturing Industry companies are listed on the Stock Exchange in 2014-2017. European Journal of Business and Management, 11(16), 103-120. DOI: 10.7176/EJBM/11-16-13

11. Swigly, C., \& Sukartha, I. M. (2015). Pengaruh Karakter Eksekutif, Komite Audit, Ukuran Perusahaan, Leverage, dan Sales Growth pada Tax Avoidance. E-Jurnal Akuntansi Universitas Udayana, 10(1), 47-62.

12. Tarmidi, D. (2019). Tax Compliance and Uncompliance Entity: A Comparative Study of Investor Reaction. International Journal of Academic Research in Accounting, Finance and Management Sciences, 9(1), 105-110. DOI: 10.6007/IJARAFMS/v9-i1/5823

13. Waluyo. (2017). The Effect of Good Corporate Governance on Tax Avoidance: Empirical Study of The Indonesian Banking Company. The Accounting Journal of Binaniaga, 02(02), 1-10. 